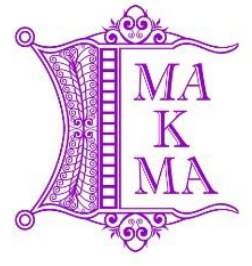

Majalah Kesehatan Masyarakat Aceh (MaKMA) http://ojs.serambimekkah.ac.id/index.php/makma

\title{
GAMBARAN TINGKAT KECEMASAN MAHASISWA TK III SEBELUM DAN SESUDAH DIBERIKAN BIMBINGAN BELAJAR SAAT MENGHADAPI UJI KOMPETENSI (Studi Kasus Di Prodi Keperawatan Tapaktuan Poltekkes Kemenkes Aceh)
}

\author{
Putro Simeulu ${ }^{凶}$
}

Dosen Prodi Keperawatan Tapaktuan Poltekkes Kemenkes Aceh

${ }^{\square}$ Kampus Keperawatan Tapaktuan Poltekkes Kemenkes Aceh. Email: Putroe_rafi@ yahoo.co.id

\begin{abstract}
ABSTRAK
Uji Kompetensi merupakan proses pengukuran penegetahuan, ketrampilan, dan perilaku peserta didik pada perguruan tinggi bidang kesehatan. Pelaksanaan uji kompetensi di Prodi Keperawatan Tapaktuan periode november 2017 jumlah peserta 161, yang lulus $124(77 \%)$ tingginya persentase tingkat kelulusan $77 \%$ disebabkan pada saat itu sudah diberikan bimbingan belajar uji kompetensi secara intensif kepada mahasiswa, khusunya yang pertama mengikuti uji kompetensi (first taker). Tujuan penelitian ini adalah untuk mengetahui gambaran tingkat kecemasan mahasiswa sebelum dan sesudah diberi bimbingan belajar dalam menghadapi uji kompetensi. Jenis Penelitian ini adalah deskriptif kuantitatif. Hasil penelitian menunjukkan bahwa mahasiswa DIII Keperawatan tingkat tiga Prodi Keperawatan Tapaktuan hampir semua dari mahasiswa $(88,37 \%)$ berada pada kategori tidak cemas, Gambaran tingkat kecemasan mahasiswa setelah diberikan bimbingan saat menghadapi uji kompetensi di Prodi Keperawatan Tapaktuan secara keseluruhan berada pada kategori kecemasan ringan yaitu $(74,41 \%)$, artinya mahasiswa merasakan cemas ringan setelah mengikuti try out institusional uji kompetensi. Uji kompetensi diberikan setelah diberikan bimbingan belajar, menurut wawancara Mahasiswa tidak merasakan cemas saat menghadapi bimbingan belajar. Saran kepada mahasiswa untuk dapat meningkatkan pola belajar dengan banyak membaca buku dan latihan soal, membuat terbiasa dan terlatih sehingga tidak merasa kecemasan yang berlebihan saat menghadapi soal ujian.
\end{abstract}

Kata Kunci: Bimbingan Belajar, Tingkat Kecemasan, Uji Kompetensi.

Riwayat Artikel 


\title{
DESCRIPTION OF THE LEVEL OF ANXIETY OF THREE LEVEL STUDENTS BEFORE AND AFTER PROVIDED LEARNING MENTORING WHEN FACING THE COMPETENCE TEST IN THE NURSING (Study Program Of The Poltekkes Kemenkes Aceh)
}

\begin{abstract}
Competency Test is the process of measuring the knowledge, skills, and behavior of students in health care colleges The competency test in Tapaktuan Nursing Study Program in the period of November 2017 numbered 161 participants, who passed 124 (77\%) a high percentage of graduation rate of $77 \%$ due to the fact that they had been given intensive competency testing to students, especially the first to take the competency test (first taker). The purpose of this study was to describe the anxiety level of students before and after being given tutoring in the face of competency tests. This type of research is quantitative descriptive. The results showed that all three nursing DIII students in Nursing Nursing Study Program, almost all of the students $(88.37 \%)$ were in the not anxious category. that is $(74.41 \%)$, meaning that students feel mild anxiety after attending an institutional competency test. Competency testing is given after being given tutoring, according to interviews Students do not feel anxious when facing tutoring. Suggestions for students to be able to improve their learning patterns by reading a lot of books and practice questions, making them familiar and trained so they do not feel excessive anxiety when facing exam questions.
\end{abstract}

Keywords: Anxiety Level, Competency Test, Tutoring. 


\section{PENDAHULUAN}

Untuk dapat menjalankan praktik keperawatan, seorang perawat wajib memiliki Surat Tanda Registrasi (STR). Sedangkan untuk mendapatkan STR perawat harus memilki sertifikat kompetensi ${ }^{[1]}$. Untuk mengukur standar kompetensi perawat dan memperoleh sertifikat kompetensi, perawat diharuskan mengikuti Uji Kompetensi. Uji Kompetensi adalah proses pengukuran penegetahuan, ketrampilan, dan perilaku peserta didik pada perguruan tinggi bidang kesehatan. Uji Kompetensi diselenggarakan untuk menghasilkan tenaga kesehatan yang kompeten sesuai dengan standar kompetensi lulusan dan standar kompetensi kerja ${ }^{[2]}$. Untuk memenuhi kemampuan tersebut maka dilakukan uji kompetensi dimana pada ujian tersebut nantinya bertujuan untuk mengukur kemampuan mahasiswa. Saat ini data tingkat kelulusan uji kompetensi cenderung fluktuasi. Presentase lulusan terjadi pada periode I tahun 2015 yaitu $29,49 \%$ untuk diploma III keperawatan, pada periode II tahun 2015 terjadi kenaikan prosentase kelulusan menjadi $64,38 \%$. $^{[3]}$

Hasil studi pendahuluan yang peneliti dapatkan angka prosentase tingkat kelulusan mahasiswa Prodi Keperawatan Tapaktuan yang mengikuti uji kompetensi adalah periode tanggal 26 November 2014 jumlah peserta 128 , mahasiswa yang lulus 10 orang $(7,81 \%)$, periode Mei 2016 jumlah mahasiswa yang mengikuti uji kompetensi 174, mahaiswa yang lulus 21 orang (12\%), periode November 2016 jumlah mahasiswa 186, yang lulus 20 orang ( $10,75 \%)$, periode April 2017 jumlah peserta 135, mahasiswa yang lulus 17 orang ( 12,60\%), peiode juli 2017 jumlah mahasiswa yang mengikuti uji kompetensi 90, mahasiswa yang lulus
20 orang $(22,2 \%)$, periode november 2017 jumlah pserta 161, yang lulus 124 $(77 \%)$ tingginya persentase tingkat kelulusan $77 \%$ disebabkan pada saat itu sudah diberikan bimbingan belajar uji kompetensi secara intensif kepada mahasiswa, khusunya yang pertama mengikuti uji kompetensi ( first taker).

Kecemasan dalam menghadapi ujian merupakan suatu manifestasi emosi yang bercampur baur yang dialami oleh individu sebagai reaksi dalam menghadapi ujian yang dapat mempengaruhi fisik dan psikis.

Terdapat empat tingkatan kecemasan yaitu kecemasan ringan, dihubungkan dengan ketegangan yang dialami sehari hari. Individu masih waspada serta lapang persepsinya meluas, menajamkan indra. Dapat memotivasi individu untuk belajar dan mampu memecahkan masalah secara efektif dan menghasilkan pertumbuhan dan kreatifitas. Kecemasan sedang, individu terfokus hanya pada pikiran yang menjadi perhatianya, terjadi penyempitan lapangan persepsi, masih dapat melakukan sesuatu dengan arahan orang lain, kecemasan berat, lapangan persepsi individu sangat sempit. Pusat perhatianya pada detil yang kecil dan sfesifik dan tidak dapat berfikir hal hal lain. Seluruh perilaku dimaksudkan untuk mengurangi kecemasan dan perlu banyak perintah / arahan untuk fokus pada area lain, dan panik, dimana individu kehilangan kendali diri dan detil perhatian hilang. Karena hilangnya kontrol, maka tidak mapu melakukan apapun meskipun dengan perintah. Terjadinya peningkatan aktivitas motorik, berkurangnya kemampuan berhubungan dengan orang lain, penyimpangan pesepsi dan hilangnya pikiran rasional, tidak mampu berfungsi secara efektif, biasanya disertai dengan disorganisasi kepribadian. ${ }^{[4]}$ 
Untuk mengurangi kecemasan, individu mempunyai mekanisme pertahanan diri yaitu mekanisme dan strategi koping. Mekanisme koping adalah cara yang dilakukan individu dalam menyelesaikan masalah, menyesuaikan diri dengan perubahan serta respon terhadap situasi yang mengancam. Berdasarkan tingkatan ansietas membutuhkan lebih banyak energi untuk mengatasi ancaman tersebut. Sedangkan strategi koping adalah cara yang dilakukan untuk mengubah lingkungan atau situasi atau menyelesaikan masalah yang sedang dirasakan / dihadapi. ${ }^{[5]}$.

\section{METODE}

Jenis Penelitian ini adalah deskriptif kuantitatif yaitu rancangan untuk melihat gambaran tingkat kecemasan mahasiswa tingkat tiga keperawatan sebelum dan sesudah mendapatkan bimbingan belajar saat menghadapi uji kompetensi di Prodi Keperawatan Tapaktuan Poltekkes Kemenkes Aceh. Penelitian ini dilaksanakan di Prodi Keperawatan Tapaktuan. Penelitian ini akan dilaksanakan pada bulan 08 Agustus sampai 01 Septmber 2018 saat dilakukan bimbingan belajar saat menghadapi uji kompetensi kesehatan periode oktober 2018. Sampel dalam penelitian ini adalah Total sampling yaitu seluruh mahasiswa tingkat tiga keperawatan yang berjumlah 43 orang yang akan mengikuti bimbingan belajar saat menghadapi uji kompetensi

\section{HASIL}

Deskripsi Responden terhadap tingkat kecemasan sebelum diberikan bimbingan UKOM Pada mahasiswa TK III Prodi Keperawatan Tapaktuan Poltekkes Kemenkes Aceh Tahun 2018 seperti pada [Tabel 1]
Faktor - faktor yang mempengaruhi strategi koping yaitu kesehatan fisik, keyakinan atau pandangan positif, ketrampilan memecahkan masalah, ketrampilan sosial, dukungan sosial dan materi. Berdasarkan latar belakang diatas peneliti ingin melakukan penelitian mengenai Gambaran tingkat kecemasan mahasiswa TK III Keperawatan sebelum dan sesudah mendapat bimbingan belajar dalam menghadapi uji kompetensi di Prodi Keperawatan Tapaktuan.

kesehatan pada periode oktober 2018. Data yang langsung diperoleh dari responden dengan menyebarkan kuesioner yang berisi pertanyaan atau pernyataan yang tentang tingkat kecemasan yang terdiri dari 14 symtom, dengan menggunakan chek list yang selanjutnya diisi oleh responden. Adapun instrumen yang digunakan dalam penelitian ini berupa kuesioner (daftar pertanyaan/pernyataan) adaptasi dari item ietm pertanyaan dalam Hamilton Anxiety Rating Scale (HARS) yang telah dimodifikasi oleh peneliti pertanyaan dalam kuesioner tersebut terdiri dari 14 syntom sesuai respon kecemasan yaitu respon fisiologis, kognitif, perilaku dan afektif. Responden memilih satu dari lima pilihan jawaban yang ada pada kuesioner dengan menggunakan skala likert

dapat diketahui bahwa mayoritas 38 $(88,37 \%)$ mahasiswa TK III keperawatan tidak mengalami cemas sebelum mengikuti bimbingan belajar UKOM, di Prodi keperawatan Tapaktuan Poltekkes Kemenkes Aceh

Deskripsi Responden terhadap tingkat kecemasan setelah diberikan bimbingan 
UKOM Pada mahasiswa TK III Prodi Keperawatan Tapaktuan Poltekkes Kemenkes Aceh dapat dilihat pada [Tabel 2]

\section{PEMBAHASAN}

\section{Sebelum bimbingan UKOM.}

Secara umum hasil penelitian menunjukkan bahwa mahasiswa DIII Keperawatan tingkat tiga Prodi Keperawatan Tapaktuan hampir semua dari mahasiswa $(88,37 \%)$ berada pada kategori tidak cemas, hanya sebagian kecil $(11,62 \%)$ yang merasakan cemas ringan yang didukung oleh respon pendukungnya, yaitu kognitif, afektif, fisiologi dan perilaku. Tidak munculnya rasa cemas pada sebagian besar mahasiswa dikarenakan belum tampaknya stimulus stresor atau ancaman bagi mahasiswa, hanya sebagian kecil yang mengalami kecemasan ringan. Menurut Stuart dan sundeen $^{[6]}$. Kecemasan ringan dapat disebabkan oleh ketegangan dalam kehidupan sehari hari. Hal tersebut menyebabkan seseorang menjadi waspada dan meningkat lahan persepsinya. Cemas dapat menjadi motivasi untuk belajar dan menghasilkan kreatifitas. Sedangkan ansietas ringan berhubungan dengan ketegangan dalam kehidupan sehari hari, anxietas pada tingkat ini menyebabkan seseorang menjadi waspada dan meningkatkan lahan persepsinya. Ansietas ini dapat memotivasi belajar dan menghasilkan pertumbuhan dan kreatifitas. ${ }^{[7]}$

\section{Setelah bimbingan UKOM.}

Gambaran tingkat kecemasan mahasiswa setelah diberikan bimbingan saat menghadapi uji kompetensi di Prodi Keperawatan Tapaktuan secara keseluruhan berada pada kategori kecemasan ringan yaitu $(74,41 \%)$, artinya mahasiswa merasakan cemas dapat diketahui bahwa mahasiswa merasakan cemas ringan sebanyak 32 $(74,41 \%)$ di Prodi keperawatan Tapaktuan Poltekkes Kemenkes Aceh.

ringan setelah mengikuti try out institusional uji kompetensi.Uji kompetensi diberikan setelah diberikan bimbingan belajar, menurut wawancara mahasiswa tidak merasakan cemas saat menghadapi bimbingan belajar. Respon afektif (emosi) pada tingkat kecemasan ringan yaitu tidak dapat duduk tenang, tremor halus pada tangan, suara kadang kadang meninggi. ${ }^{[7]}$

Respon afektif berupa mudah terganggu, tidak sabar, gelisah dan tegang, ketakutan, kecemasan, khaatir dan gugup. ${ }^{[8]}$ Respon afektif yang tidak terkendali dalam menghadapi ujian adalah kecemasan yang muncul sebagai akibat mahasiswa merasakan perasaan yang berlebihan saat menghadapi ujian yang diwujudkan dalam bentuk perasaan khawatir, gelisah dan takut dalam menghadapi ujian terutama pada mata kuliah yang dianggap sulit oleh mahasiswa. Berdasarkan hal tersebut, maka indikator kondisi afektif dalam menghadapi ujian kompetensi yaitu : takut, khawatir dan gelisah. Tidak terkendalinya konsep afektif tersebut disebabkan oleh cara pandang mahasiswa yang membayangkan bahwa uji kompetensi yang akan dihadapinya terlampau sulit, takut tidak lulus dan membayangkan akan kegagalan. Tingkat kecemasan mahasiswa TK III Keperawatan berdasarkan respon kognitif berada pada kategori cemas ringan $(74,41 \%)$, sedikit tidak mengalami cemas $(11,62 \%)$ dan sedikit yang mengalami cemas berat $(13,95 \%)$. Menurut Dalami at el. (2009), respon kognitif pada tingkat kecemasan ringan yaitu lapangan persepsi melebar, mampu menerima rangsangan yang komplek, konsentrasi pada masalah, menjelaskan masalah secara efektif. ${ }^{[9]}$ 
Respon kognitif yang tidak terkendali dalam menghadapi ujian adalah munculnya kecemasan sebagai akibat dari cara berpikir mahasiswa yang tidak terkondisikan yang seringkali memikirkan tentang kejadian yang buruk yang akan terjadi. Adapun indikator respon kognitif dalam kecemasan adalah sulit konsentrasi, bingung dan mental blocking. ${ }^{[9]}$

Respon fisiologis individu terhadap kecemasan, yaitu : Kardiovaskuler : responnya berupa palpitasi, jantung berdebar,tekanan darah meningkat atau menurun, rasa mau pinsan, dan denyut nadi menurun. Pernafasan : responya berupa nafas cepat dan dangkal, nafas pendek, tekanan pada dada, pembengkakan pada tenggorokan, sensasi tercekik, dan terengah engah. Nuromuskuler : responnya berupa reflek meningkat, reaksi kejutan, mata berkedip-kedip, tremor, gelisah, wajah tegang, kelemahan umum, kaki goyang, dan gerakan yang janggal. Gastrointestinal : responya berupa kehilangan berupa kehilangan nafsu makan, menolak makan, rasa tidak nyaman pada abdomen, mual dan diare. Traktus

\section{KESIMPULAN}

Berdasarkan hasil penelitian yang dilakukan pada mahasiswa TK III Prodi Keperawatan Poltekkes Kemenkes Aceh, sebelum dan setelah diberikan bimbingan belajar dalam menghadapi Uji Kompetensi Nasional Periode Oktober Tahun 2018 pada 43 responden, maka dapat disimpulkan bahwa :

Sebelum diberikan bimbingan belajar, hampir keseluruhan dari mahasiswa $(88.37 \%)$ tidak mengalami gejala kecemasan. Setelah diberikan uji try out soal dalam bentuk setingan yang sama hampir sama dengan uji urinarius : responya berupa sering berkemih, tidak dapat menahan BAK. Kulit : responya berupa wajah kemerahan, berkeringat setempat (telapak tangan), gatal, rasa panas dan dingin pada kulit, wajah pucat, dan berkeringat seluruh tubuh. ${ }^{[8]}$ Gejala fisiologis kecemasan yang dirasakan mahasiswa dalam menghadapi tes atau ujian seperti gangguan lambung, rasa mual, berkeringat, tangan dingin dan lembab, buang air kecil, mulut kering, tangan atau tubuh gemetar, dan dada berdebar-debar. ${ }^{[10]}$ Respon perilaku berupa gelisah, ketegangan fisik, tremor, gugup, bicara cepat, kurang koordinasi, cenderung mendapat cidera, menrik diri dari hubungan interpersonal, menghalangi dan menghindari dari masalah. ${ }^{[8]}$

Gemetar adalah suatu gerakan yang dilakukan tampa sengaja, karena merasakan suatu ancaman ketika menghadapi ujian seperti diharuskan untuk menjawab soal dengan cepat, diharuskan duduk di depan dan keterbatasan waktu yang tersedia saat ujian. Semua gerakan ini tampa disadari dapat mempengaruhi tangan, lengan, kepala, ajah, pita suara dan kaki. ${ }^{[9]}$

kompetensi nasional maka didapatkan hasil, sebagian besar $(74,41 \%)$ mahasiwa mengalami tingkat kecemasan ringan.

Disarankan kepada mahasiswa TK III Prodi Keperawatan Tapaktuan Poltekkes Kemenkes Aceh untuk terus dapat meningkatkan pola belajar dengan banyak membaca buku dan latihan soal sehingga dapat memecahkan soal-soal dengan cepat dan tepat, sering berlatih membuat mahasiswa menjadi terbiasa dan terlatih sehingga tidak merasa kecemasan yang berlebihan saat menghadapi soal ujian. Kepada dosen pembimbing untuk bisa meningkatkan 
diri untuk terus belajar mengasah diri dan ilmu dengan banyak membaca, dan melatih cara membuat soal vitgnet yang bagus, menyiapkan bank soal untuk menyimpan soal yang berkualitas yang bisa diuji kan kepada mahasiswa,

\section{DAFTAR PUSTAKA}

1. Nursalam. (2012). Manajemen Keperawatan : Aplikasi Dalam Praktek Keperawatan Pofesional. Jakarta : Salemba Medika

2. Suherman , (2005). Bimbingan Belajar. Jakarta : UPI http;//respiratori UPI.

3. Anggraeni, N. (2015). Gambaran Tingkat Kecemasan Pada Mahasiswa Tingkat Tiga Prodi D3 Keperawatan dalam menghadapi Uji Kompetensi di Universitas Pendidikan Indonesia Jakarta : Tidak diterbitkan.

4. Hawari, Dadang. (2011). Manajemen Stres, Cemas dan Depresi. Jakarta : FKUI pp.63-6.

5. Hawari, Dadang. (2009). Psikometri alat Ukur (Skala) Kesehatan Jiwa.Jakarta : FKUI pp-63.

6. Navianti, E. (2011). Hubungan Dukungan Perawat dengan tingkat kecemasan orang tua di Ruang rawat anak RSAB Harapan kita Jakarta. Tesis Magister Keperawatan Pada FIK UI Depok Pada FIK UI Depok : tidak diterbitkan. sehingga dapat mengurangi kecemasan bagi mahasiswa ketika menghadapi uji kompetensi. Semoga uji kompetensi nantinya banyak mahasiswa yang mempunyai nilai kompeten/lulus.

7. Dalami,E. Et al. (2009). Asuhan Keperawatan jiwa dengan dengan masalah Psikososial. Jakarta : CV.Trans Info Media.

8. Astria, Y. (2002). Hubungan karakteristik ibu hamil trimester III dengan kecemasan dalam menghadapi perslinan di Poliklinik kebidanan dan kandungan RSUP Fatmawati. Skripsi Keperawatan pada FKIK UIN Syarif Hidayatulloh Jakarta : Tidak di Terbitkan

9. Tresna (2011). Efektivitas konseling behavioral dengan tehnik desensitisasi sistematis untuk mereduksi kecemasan menghadapi ujian. Tesis studi bimbingan dan konseling UPI bandung : Tidak di terbitkan.

10. Komalasari, G. Dan Herdi (2011). Coping Skills untuk mengatasi kecemasan menghadapi ujian Nasional pada siswa Sekolah menengah atas Negeri di Provinsi DKI Jakarta. Universitas Negeri Jakarta : Tidak diterbitkan. 


\section{LAMPIRAN}

Tabel [1]. Distribusi Frekuensi Berdasarkan Tingkat Kecemasan

\begin{tabular}{lcc}
\hline \multicolumn{1}{c}{ Tingkat Kecemasan } & Frekwensi & Persentase \\
\hline Tidak cemas & 38 & 88,37 \\
Cemas ringan & 5 & 11,62 \\
Cemas sedang & - & - \\
Cemas berat & - & - \\
Cemas berat sekali & - & - \\
\hline \multicolumn{1}{c}{ Jumlah } & & 100 \\
\hline
\end{tabular}

Tabel [2]. Distribusi Frekuensi Berdasarkan Tingkat Kecemasan

\begin{tabular}{lcc}
\hline \multicolumn{1}{c}{ Tingkat Kecemasan } & Frekwensi & Persentase \\
\hline Tidak cemas & 5 & 11,62 \\
Cemas ringan & 32 & 74,41 \\
Cemas sedang & 6 & 13,95 \\
Cemas berat & - & - \\
Cemas berat sekali & - & - \\
& & $\mathbf{1 0 0}$ \\
\hline \multicolumn{1}{c}{ Jumlah } & $\mathbf{4 3}$ & \\
\hline
\end{tabular}

